\title{
The European Union Criminal Policy against Corruption: Two Decades of Efforts
}

\section{La política criminal de la Unión Europea contra la corrupción: dos décadas de esfuerzos}

\author{
Demelsa Benito Sánchez \\ Lecturer of Criminal Law - University of Deusto (Spain) \\ demelsa.benito@deusto.es
}

\begin{abstract}
Corruption has been in the agenda of the European Union for decades due to its devastating effects on the political and economic systems of the EU Member States, and on the European Union itself. Therefore, with the aim of combating corruption, the European Union has adopted a wide list of legal instruments since the middle of the nineties that Member States shall implement and enforce. This paper offers a critical review of the main instruments, from the first initiatives, adopted already two decades ago, until the most recent ones, focusing on the criminal law obligations they impose on the Member States. Likewise, it analyses the implementation and enforcement of such documents by Member States, with the final purpose of assessing if the European Union criminal policy against corruption is working correctly or, by contrast, needs to be improved.
\end{abstract}

Keywords: Corruption, criminal policy, European Union, Member State, public official.

\section{Resumen}

La corrupción ha estado presente en la agenda de la Unión Europea desde hace décadas debido a sus devastadores efectos sobre los sistemas políticos y económicos de los Estados Miembros, y sobre la propia Unión Europea. Por eso, y con el objetivo de combatir la corrupción, desde mediados de los años noventa, la Unión Europea ha adoptado un amplio listado de instrumentos legales que los Estados Miembros deben implementar y aplicar. Este trabajo ofrece una revisión crítica de los principales instrumentos, desde los primeros, adoptados hace ya dos décadas, hasta los más recientes, poniendo el énfasis en las obligaciones penales que ellos imponen a los Estados miembros. Igualmente, este trabajo analiza cómo está siendo la implementación y aplicación de tales instrumentos por los Estados Miembros, con el objetivo final de valorar si la política criminal de la Unión Europea contra la corrupción está funcionando correctamente o si, por el contrario, necesita una mejora.

Palabras clave: Corrupción, política criminal, Unión Europea, Estado miembro, funcionario público. 


\section{Introduction}

Corruption is one of the main problems of the current world. It hinders economic development, undermines democracy and causes human suffering ${ }^{1}$. Therefore, corruption has been in the agendas of the principal international organisations for more than two decades, as well as in the agendas of national governments. The European Union is not an exception. It has been very aware of this problem for years, and although most of the Member States of the European Union are among the best positions in the Corruption Perception Index elaborated by Transparency International, ${ }^{2}$ corruption continues to be a challenge for the European Union, because apart from the aforementioned consequences, it may harm the EU itself.

It was already twenty years ago, in May 1997, when the European Union adopted a convention against corruption: the Convention on the fight against corruption involving officials of the European Communities or officials of Member States of the European Union. It is unquestionable that this document represents a milestone in the EU criminal policy against corruption because for the first time, a legal document required Member States of the European Union to criminalise bribery of public officials in general.

Before the adoption of the Convention of 1997, there were other documents on corruption. However, the approach to corruption in such documents was very restrictive since they demanded Member States the criminalisation of corruption only if it put or may put the financial interests of the European Union at risk. The EU Convention on corruption, by contrast, requires Member States to penalise corruption in any case, even though the financial interests of the European Union are not affected.

The EU Convention on corruption is, thus, the most relevant document on the matter at the EU level, and also, the first binding legal document for the European countries which demands the criminalisation of corruption in general. ${ }^{3}$ Then, other legal documents on this matter adopted in the framework of other organisations would be binding for the European countries too. Namely, the Convention on Combating Bribery of Foreign Public Officials in International Business Transactions, adopted by the Organisation for Economic Co-operation and Development at the end of 1997, has been ratified by 24 Member States of the EU. The Council of Europe Conventions on Corruption (Criminal Law Convention and Civil Law Convention), both adopted in 1999, have been ratified by the 28 Member States of the EU. Finally, the United

\footnotetext{
${ }^{1}$ The research leading to this paper has been developed within the framework provided by the research group Mutations of public power and the transnational law (Basque Government, Spain, 2016-2018, reference: IT997-16), the research project La reforma del decomiso y la recuperación de activos derivados del delito (Government of Spain, 2016-2019, reference: DER2016-79895), and the SAPIA Jean Monnet Module (Students' Awareness of Public Integrity and Accountability), awarded by the European Commission (2017-2020, 586939-EPP-1-2017-1-ES-EPPJMO-MODULE).

2 The Corruption Perceptions Index measures the perceived levels of public sector corruption worldwide. Results are available at

https://www.transparency.org/whatwedo/publication/corruption_perceptions_index_2016 (last access 22.12.2017). According to the 2016 Corruption Perceptions Index, 21 EU Member States are among the 50 first countries of the ranking, which includes 176 countries. The last EU Member State in the ranking is Bulgaria, in position 75 .

3 The Inter-American Convention on Corruption, adopted under the auspices of the Organization of American States in 1996, is the first binding legal document on corruption adopted by an international organisation.
} 
Nations Convention on Corruption, ${ }^{4}$ adopted in 2003, is binding for all Member States of the European Union too. ${ }^{5}$

As said, the EU Convention on corruption was adopted in 1997. However, at that time, EU Member States did not seem to be very worried about corruption, as proved by the fact that the EU Convention on corruption took eight years to get the needed number of ratifications to entry into force. ${ }^{6}$ That was in 2005 , when even the United Nations Convention on Corruption, passed six years later, had already been adopted.

The European Union, aware of the indifference of its Member States to fighting bribery, launched a Communication in 2003 entitled "Communication from the Commission to the Council, the European Parliament and the European Economic and Social Committee - On a comprehensive EU policy against corruption". 7 This document set out an overview of what had been achieved at the EU level, and also contained a list of pending tasks to give fresh impetus to the fight against corruption, among them, encouraging the ratification of the existing legal documents on corruption by Member States. In the following years, other legal documents on the matter came to light with the aim of strengthening the fight against bribery.

This paper offers a critical review of the main EU legal documents on corruption, from the first initiatives, adopted in the middle of the nineties, until the most recent ones, focusing on the criminal law obligations they impose on the Member States. Moreover, it analyses the implementation and enforcement of such documents by Member States, with the final purpose of assessing if the European Union criminal policy against corruption is working correctly or, by contrast, needs to be improved. The thesis defended in this paper that, notwithstanding the efforts and progresses made at the EU level for the last twenty years, which must be assessed as very positive, there is still much work to do in this field because, as it will be explained, the evidence shows that corruption continues to be a crucial problem for the EU itself and for the Member States. In particular, EU policy against corruption should put more emphasis on preventive measures, which have been partially ignored for years, while the focus has been put on criminalisation. But even with respect to the latter, policies should be reviewed because the data shows that there are still many discrepancies among Member States regarding implementation of such measures (e.g. criminalisation of private corruption). Moreover, EU criminal policy to combat corruption should also take into account the necessity of coordinate strategies between the Member States, and also between them and the EU institutions because corruption is no longer a national issue,

\footnotetext{
${ }^{4}$ UN General Assembly Resolution 58/4 of 31.10.2003.

${ }^{5}$ Even the European Union itself, as an organisation which has legal personality, is a Party in the United Nations Convention on Corruption.

${ }^{6}$ Actually, the Eurobarometer has not traditionally asked about the problem of corruption at the EU level, so it is not possible to know exactly the opinion of the European citizens at the time the EU Convention on corruption came to light. The Special Eurobarometer on Corruption, published in February 2014, shows that three-quarters of respondents $(76 \%)$ thought that corruption is widespread in their own country. See EUROPEAN COMMISSION, Special Eurobarometer 397. Corruption. Report, February 2014, p. 18 (available at http://ec.europa.eu/commfrontoffice/publicopinion/archives/ebs/ebs_397_en.pdf, last access 22.12.2017). In the case of Spain, for instance, the barometer elaborated by the Centro de Investigaciones Sociológicas in October 1997, when the EU Convention on corruption was adopted, indicated that only $3 \%$ of the respondents considered corruption a problem in the country. The barometer published in July 2017 shows that this figure amounts to $45,3 \%$ (available at http://www.cis.es/cis/opencm/EN/11_barometros/index.jsp, last access 22.12.2017).

${ }^{7}$ Brussels, 28.5.2003, COM (2003) 317 final.
} 
but a transnational one, usually linked to other transnational criminal activities such as organised crime and money laundering, as stated at the Preamble of the United Nations Convention against Corruption (hereinafter, UNCAC) ${ }^{8}$.

This work starts with a section devoted to the always polemic definition of corruption and the consequences of this phenomenon, particularly, at the EU level. Then, the second section offers a study of the legal framework for an anti-corruption policy in the European Union, taking into account the special structure of this organisation, and the evolution of the problem of corruption in the agenda of the European Union. Thirdly, the main EU legal documents on corruption are studied, paying special attention to the obligations in criminal matters. The fourth section briefly analyses the implementation and enforcement of such documents, on the basis of several reports elaborated by different international organisations. Finally, some conclusions are offered.

\section{Definition and consequences of corruption}

Offering a generally accepted definition of corruption is a complex task. ${ }^{9}$ The term corruption includes a wide range of conducts. The list of conducts can even vary over time and from one territory to another. For this reason, a definition of corruption does not appear in legal documents. Not even the aforementioned UNCAC dares to define it. It simply points out a list of behaviours to be criminalised by the States Parties. This list includes, among others, bribery, embezzlement, trading in influence, abuse of functions and illicit enrichment. The absence of a univocal definition of corruption and the reference to a variety of conducts may be an important obstacle in the fight against corruption since it can hinder the adoption of coordinated policies. ${ }^{10}$ However, at least generally speaking, one can find a commonly accepted definition of corruption: "the abuse of entrusted power for private gain". "Traditionally, this power has been public, in the sense of being exercised by a public official. However, for nearly two decades, it is understood that this power can be also private, so that the term corruption is nowadays used to refer to behaviours that occur in the private sector too. ${ }^{12}$

At the European level, and despite the aforementioned difficulties, a definition of corruption was already given in 1995 by the European Parliament in its Resolution on combating corruption in Europe ${ }^{13}$ :

\footnotetext{
${ }^{8}$ Regarding the links between corruption and organised crime, see, for instance, GOUNEV, Philip; BEZLOV, Tihomir, Examining the links between organised crime and corruption, Center for the Study of Democracy, 2010. With respect to the links between corruption and money laundering, see, for instance, CHAIKIN, David; SHARMAN, Jason C., Corruption and Money Laundering. A Symbiotic Relationship, Palgrave Macmillan, New York, 2009.

${ }^{9}$ On the problems to define corruption, see the work of GARDINER, John, 'Defining corruption', in HEIDENHEIMER, Arnold J.; JOHNSTON, Michael (Eds.), Political corruption. Concepts and Contexts, Transaction Publishers, 3rd edn., New Brunswick / London, 2005, pp. 25-40.

${ }^{10}$ FEROLA, Laura, 'Anti-Bribery Measures in the European Union: A Comparison with the Italian Legal Order', International Journal of Legal Information, n. 28-3 (2000), pp. 512-557, p. 516 TIVIG, Andrea; MAURER, Andreas, Die EU-Antikorruptionspolitik. Erfolgsbedingungen einer Korruptionsbekämpfung auf mehreren Ebenen, Diskussionspapier der FG 1, 2006/03, March 2006, SWP Berlin, p. 5.

11 TRANSPARENCY INTERNATIONAL, The Anti-Corruption Plain Language Guide, 2009, p. 14.

12 See, for instance, the Council Framework Decision 2003/568/JHA of 22 July 2003 on combating corruption in the private sector (OJ L 192 of 31.7.2003).

${ }^{13}$ OJ C 17 of 22.1.1996.
} 


\section{Decades of Efforts".}

"the behavior of persons with public or private responsibilities who fail to fulfil their duties because a financial or other advantage has been granted or directly or indirectly offered to them in return for actions or omissions in the course of their duties".

Although several conducts can be included in this definition, the European legal documents concerning this matter always identify corruption with bribery, and this is the meaning of the term corruption that will be used in this paper.

The existing literature on the consequences of corruption is very wide and it is not an aim of this work to exhaust it to complete it. ${ }^{14}$ It is commonly accepted that corruption is a serious threat to the democratic system and economic development. ${ }^{15}$ The Preamble of the UNCAC states that corruption threatens "the stability and security of societies, undermining the institutions and values of democracy, ethical values and justice and jeopardizing sustainable development and the rule of law". Consequences of corruption are even worse when it appears in conjunction with other criminal activities, specially, organised crime. Corruption also has a serious impact on human rights. ${ }^{16}$

More precisely, at the economical level, corruption reduces investment (for both domestic and foreign entrepreneurs), distorts public expenditures, eliminates free competition and increases inequality. In a few words, corruption impedes economic growth $^{17}$. At the political level, corruption generates a feeling of distrust in citizens

\footnotetext{
${ }^{14}$ See, among others, BERDUGO GÓMEZ DE LA TORRE, Ignacio; FABIÁN CAPARRÓS, Eduardo A., 'Corrupción y derecho penal: nuevos perfiles, nuevas respuestas', Revista Brasileira de Ciências Criminais, n. 81 (2009), pp. 6-35; CARTIER-BRESSON, Jean, 'The Causes and Consequences of Corruption: Economic Analyses and Lessons Learnt, No Longer Business As Usual', in No Longer Business as Usual. Fighting Bribery and Corruption, OECD Publications, Paris, 2000, pp. 11-28; CHÊNE, Marie, The impact of corruption on growth and inequality, Transparency International, 2014; GUPTA, Sanjeev; DAVOODI, Hamid; ALONSO-TERME, Rosa, Does Corruption Affect Income Inequality and Poverty?, International Monetary Fund Working Paper 98/76, 1998; LAMBSDORFF, Johann G., 'Consequences and Causes of Corruption - What do We Know from a Cross-Section of Countries?' in ROSE-ACKERMAN, Susan (Ed.), International Handbook on the Economics of Corruption, Edward Elgar Publishing, Northampton, 2006, pp. 3-49; MAURO, Paolo, 'The Effects of Corruption on Growth, Investment, and Government Expenditure: A Cross-Country Analysis', in ELLIOT, Kimberly. A. (Ed.), Corruption and the Global Economy, Institute for International Economics, Washington, 1997, pp. 83-116; PELLEGRINI, Lorenzo; GERLAGH, Reyer, 'Corruption's Effects on Growth and its Transmission Channels', Kyklos, n. 57 (2004), pp. 429-456; ROSE-ACKERMAN, Susan; PALIFKA, Bonnie J., Corruption and Government: Causes, Consequences and Reform, Cambridge University Press, $2^{\text {nd }}$ ed., Cambridge, 2016; TANZI, Vito, Corruption Around the World: Causes, Consequences, Scope, and Cures, International Monetary Fund Working Paper, 98/63, 1998.

${ }^{15}$ Nowadays, positions defending positive effects of corruption seem to be overcome. Some economists suggested that corruption could foster growth, for instance, by removing government-imposed rigidities which hinder investment, reducing government consumption and increasing trade openness. See, more in detail, HODGE, Andrew, SHANKAR, Sriram, RAO, D. S. Prasada; DUHS, Alan, Exploring the links between corruption and growth, School of Economics Discussion Paper No. 392, University of Queensland, June 2009.

${ }^{16}$ See Council of Europe Resolution (97) 24 on the twenty Guiding Principles for the fight against corruption, of 6.11.1997; Council of Europe Recommendation No. R (2000) 10 of the Committee of Ministers to Member states on codes of conduct for public officials, of 11.5.2000; and Council of Europe Recommendation No. R (2003) 4 on common rules against corruption in the funding of political parties and electoral campaigns, of 8.4.2003. In particular, see TRANSPARENCY INTERNATIONAL, Global Corruption Report, Berlin, 2005, p. 1: “Corruption doesn't just line the pockets of political and business elites; it leaves ordinary people without essential services, such as life-saving medicines, and deprives them of access to sanitation and housing. In short, corruption costs lives" (emphasis added).

${ }^{17}$ See ROSE-ACKERMAN /; PALIFKA, Corruption and Government..., cit. note n. 14.
} 
towards public institutions and political processes, undermining thus the legitimacy of democratic institutions and damaging the rule of law. ${ }^{18}$

At the EU level, corruption started to be present on the agenda of the institutions due to its economic effects only. Indeed, corruption has always been seen as a threat to the financial interests of the EU, and as such, a threat to the existence of the EU itself. ${ }^{19}$ Financial interests play such an important role for the EU that an attack to them is comparable to crimes against the State at the domestic level, or crimes against Humanity at the international level. ${ }^{20}$ In addition to this, corruption is also a serious threat to the internal market. ${ }^{21}$ Moreover, political consequences of corruption can also be devastating for the EU since the erosion of citizens' confidence in the EU institutions may put the process of the European integration at risk. ${ }^{22}$

\section{Combating corruption at the European Union}

\subsection{Legal framework for an anti-corruption policy at the EU level}

After the Treaty of Lisbon, ${ }^{23}$ the legal basis to fight against corruption is found in Article 83 of the Treaty on the Functioning of the European Union ${ }^{24}$ (hereinafter, TFEU). The first paragraph of this Article allows the European Parliament and the Council to establish minimum common rules

"concerning the definition of criminal offences and sanctions in the areas of particularly serious crime with a cross-border dimension resulting from the nature or impact of such offences or from a special need to combat them on a common basis".

The second paragraph of the Article expressly mentions "corruption" as one of the areas of particularly serious crime (the so-called "Euro-crimes"), therefore providing the needed legal basis for the action of the European Union in this field.

Although Article 83 of the TFEU is the fundamental legal basis, another two Articles of the same document may provide legal basis to the fight against corruption as well; namely, Articles 67 and 325. The first one, also placed in Title V (Area of freedom, security and justice) of Part Three (Union policies and internal actions), requires the European Union to

"ensure a high level of security through measures to prevent and combat crime $[\ldots]$, and through measures for coordination and cooperation between police and

\footnotetext{
${ }^{18}$ SELIGSON, Mitchell A., 'The Impact of Corruption on Regime Legitimacy: A Comparative Study of Four Latin American Countries', The Journal of Politics, n. 64 (2002), pp. 408-433.

${ }^{19}$ MANACORDA, Stefano, La corruzione internazionale del pubblico agente. Linee dell'indagine penalistica, Casa Editrice Dott. Eugenio Jovene, Naples, 1999, p. 210.

${ }^{20}$ SOTIS, Carlos, 'El huevo o la gallina: los intereses financieros de la Unión Europea y la armonización penal', in DELMAS-MARTY, Mireille; PIETH, Mark; SIEBER, Ulrich (Dir.), Los caminos de la armonización penal, Tirant lo Blanch, Valencia, 2009, p. 334.

${ }^{21}$ TIVIG/MAURER, Die EU-Antikorruptionspolitik..., cit. note n. 10, p. 7-8.

${ }^{22}$ SZAREK-MASON, Patrycja, The European Union's Fight against Corruption. The Evolving Policy Towards Member States and Candidate Countries, Cambridge University Press, Cambridge, 2010, p. 69.

${ }^{23}$ Treaty of Lisbon amending the Treaty of European Union and the Treaty establishing the European Community, OJ C 306 of 17.12.2007.

${ }^{24}$ Consolidated Version of the Treaty on the Functioning of the European Union, OJ C 326 of 26.10.2012.
} 
judicial authorities and other competent authorities, as well as through the mutual recognition of judgments in criminal matters and, if necessary, through the approximation of criminal laws".

This Article refers to crime in general, which obviously includes corruption. Article 325, in Title II (Financial provisions) of Part Six (Institutional and financial provisions) orders Member States to

"counter fraud and any other illegal activities affecting the financial interests of the Union through measures to be taken in accordance with this Article, which shall act as a deterrent and be such as to afford effective protection in the Member States, and in all the Union's institution, bodies, offices and agencies".

As known, corruption and fraud to the financial interests of the Union are two areas related to each other. ${ }^{25}$

The EU legal documents to combat corruption were adopted, however, before the Treaty of Lisbon, within the framework provided by the third pillar, which was more limited than the current framework. Some measures against corruption could have been adopted within the first pillar, as corruption may affect the internal market and the financial interests. $^{26}$ Nevertheless, the final option was to make use of the mechanisms of intergovernmental cooperation provided by the third pillar. The reason may be found in the traditional reluctance of Member States to transfer further competences in criminal matters. $^{27}$

\subsection{Corruption in the agenda of the European Union}

It was in the seventies when the international community started to pay attention to the phenomenon of corruption, particularly in the framework of the United Nations, the Organisation for Economic Co-operation and Development, and the International Chamber of Commerce ${ }^{28}$. The European Communities also expressed their concerns about corruption in those years. In a Draft for a Treaty in year $1976,{ }^{29}$ Member States were already required to criminalise bribery of officials of the European Communities. Nevertheless, this draft was abandoned, so that the fight against corruption remained at the expense of the Member States for years, most of which were concerned about their domestic officials only, ignoring corruption involving officials of the European Communities or officials of other EU Member States. Unfortunately, this resulted in the fact that the EU criminal policy against corruption was blocked for nearly two decades,

\footnotetext{
25 See, for instance, WARNER, Carolyn M., 'Creating a Common Market for Fraud in the European Union', The Independent Review, n. 2 (2003), pp. 249-257.

${ }^{26}$ WOUTERS, Jan; RYNGAERT, Cedric; CLOOTS, Ann S., 'The international legal framework against corruption: Achievements and Challenges', Melbourne Journal of International Law, n. 14 (2013), pp. 205-280, p. 223.

27 ARNONE, Marco; BORLINI, Leonardo S., Corruption: Economic Analysis and International Law, Edward Elgar Publishing Limited, Northampton, 2014, p. 238 SZAREK-MASON, The European Union's Fight Against Corruption ..., cit. note n. 22.

${ }^{28}$ See, for instance, the UN Resolution on Measures against corrupt practices of transnational and other corporations, their intermediaries and others involved, adopted in 1975 (A/RES/3514(XXX), the OECD Guidelines for multinational enterprises (1976), and the International Chamber of Commerce Rules of Conduct and Recommendations to Combat Extortion and Bribery (1977).

${ }^{29}$ Draft for a Treaty amending the Treaty establishing a Single Council and a Single Commission of the European Communities so as to permit the adoption of common rules on the liability and protection under criminal law of officials and other servants of the European Communities (OJ C 222 of 22.9.1976).
} 
and thus, it separated from the anti-corruption policy implemented, for instance, by the United States, which at that time passed the well-known Foreign Corrupt Practices $A c t,{ }^{30}$ the first law in criminalising corruption of foreign officials; a law that had later a crucial influence on the international criminal policy against corruption. ${ }^{31}$ It took twenty years for the fight against corruption to be resumed on the agenda of the European Union; undoubtedly, many wasted years.

In short, no initiatives against corruption were adopted at the EU level until the nineties, the same as at the international level. ${ }^{32}$ During this decade, the concern about corruption rose due to the enormous magnitude of the phenomenon and its devastating consequences. ${ }^{33}$ In addition to this, the United States put pressure on the European countries in order for them to adopt anti-corruption rules similar to the aforementioned Foreign Corrupt Practices Act. ${ }^{34}$ Moreover, the change of attitude in the European Union was motivated by another reason: the disclosure of a number of scandals related to the management of EU funds. ${ }^{35}$ A clear example was the resignation of the Santer Commission after the publication of a report elaborated by a Committee of Independent Experts stating the involvement of some commissioners in cases of nepotism. ${ }^{36}$

Only a few years before, in 1995, the Resolution on combating corruption in Europe had come to light. It pointed out the devastating effects of corruption for the democratic system, the internal market and the financial interests of the European Union, and encouraged Member States to adopt "appropriate and effective anti-corruption measures [...], both in connection with the protection of the EU's financial interests and beyond such protection". ${ }^{37}$ These last words were incorporated to the text with the aim of expanding the scope of application of the former Council Resolution on the legal protection of the financial interests of the Communities of $6.12 .1994^{38}$, which limited the criminalisation of corruption to cases related to the financial interests of the European Communities. Indeed, and as explained below, at the beginning, the fight against corruption at the EU level was determined by the protection of the financial interests, which really restricted the criminal policy in this field. Fortunately, this idea

\footnotetext{
${ }^{30}$ Foreign Corrupt Practices Act of 1977, as amended, 15 U.S.C. $\S \S 78 d d-1$, et seq.

31 NIETO MARTÍN, Adán, 'La privatización de la lucha contra la corrupción', in ARROYO ZAPATERO, Luis; NIETO MARTÍN, Adán (Dir.), El Derecho Penal Económico en la era compliance, Tirant lo Blanch, Valencia, 2013, pp.194-196.

${ }^{32}$ See the Inter-American Convention on Corruption, adopted by the Organization of American States in 1996, the OECD Convention on Combating Bribery of Foreign Public Officials in International Business Transactions (1997), the Council of Europe Criminal Law Convention on Corruption (1999) and the Council of Europe Civil Law Convention on Corruption (1999).

${ }^{33}$ Note that a number of studies were published in the nineties blowing the whistle on the negative effects of corruption on economic and political systems. See, e.g. GUPTA / DAVOODI / ALONSO-TERME, Does Corruption Affect Income Inequality and Poverty?, cit. note n. 14 MAURO, 'The Effects of Corruption on Growth...", cit. note n. 14; TANZI, Corruption Around the World: Causes, Consequences, Scope, and Cures, cite note n. 14.

${ }^{34}$ NIETO MARTÍN, Adán, ‘¿Americanización o europeización del Derecho Penal económico?', Revista Penal, n. 19 (2007), pp. 120-136 WHITE, Simone, Protection of the Financial Interests of the European Communities: The Fight against Fraud and Corruption, Kluwer Law International, The Hague / London / Boston, 1998, pp. 161-162.

${ }^{35}$ WHITE, Protection of the Financial Interests..., cit. note n. 34, p. 140.

${ }^{36}$ VERVAELE, John, 'Towards an independent European agency to fight fraud and corruption in the EU?', in ALBRECHT, Hans J.; KLIP, André (eds), Crime, Criminal Law and Criminal Justice in Europe, Martinus Nijhoff Publishers, Leiden / Boston, 2013, pp. 527-529.

${ }^{37}$ Emphasis added.

${ }^{38}$ OJ C 335 of 14.12.1994.
} 
was overcome with time. In addition to this, and importantly, the criminal policy against corruption started to be narrowly related to the criminal policy against other offences which typically appeared in connection to it (e.g. organised crime and money laundering).

With respect to the relationship between corruption and organised crime, the Action Plan against organised crime of year $1997^{39}$ asked for a global anti-corruption policy, mainly focusing on preventive measures and taking into account the efforts made in other international fora. ${ }^{40}$ In response to the Action Plan, the Commission presented in the same year a Communication to the Council and the European Parliament on a Union policy against corruption. ${ }^{41}$ The Communication did not focus only on repressive measures, but also on preventive ones. So, on the one hand, the Communication asked Member States for the criminalisation of bribery of foreign officials and officials of international organisations, including the European Union. Remember that until that date, States criminalised only corruption of domestic officials. On the other hand, the Communication asked Member States for the adoption of preventive measures such as banning of tax deductibility of bribes, adoption of rules on public procurement procedures and the introduction of accounting and auditing standards. However, and despite the contents of the Communication, the EU criminal policy on corruption has mainly focused on the adoption of repressive measures for years, ignoring somehow the preventive ones until very recent time, which must be criticised since it is undeniable that the best policy against any crime is always a policy of prevention.

The 1998 Council Action Plan ${ }^{42}$ included corruption among the offences to be combated in the "area of security", and in order to achieve this, minimum rules related to the constituent elements of this offence and applicable penalties had to be established. Only a few days after the adoption of the Action Plan, the Council passed the Resolution of 21 December 1998 on the prevention of organised crime with reference to the establishment of a comprehensive strategy for combating it. ${ }^{43}$ This Resolution perseveres on the links between organised crime and corruption, and describes a number of measures to prevent this kind of offences, namely the need for transparency in areas such as public procurement and funding of political parties.

The conclusions of the European Council of Tampere on the creation of an area of freedom, security and justice in the European Union (1999) included corruption, in the context of financial crime, among the list of offences with respect to which common definitions, incriminations and sanctions should be agreed.

\footnotetext{
${ }^{39}$ Adopted by the Council on 28 April 1997, OJ C 251 of 15.8.1997.

${ }^{40}$ In order to protect de EU interests and to avoid duplicities or incompatibilities between the EU anticorruption instruments and other international instruments on corruption, two Common Positions were adopted: Common Position of 6 October 1997 defined by the Council on the basis of Article K.3 of the Treaty on European Union on negotiation in the Council of Europe and the OECD relating to corruption (97/661/JHA, OJ L 279 of 13.10.1997), and Second Common Position of 13 November 1997 defined by the Council on the basis of Article K.3 of the Treaty of European Union on negotiation in the Council of Europe and the OECD relating to the fight against corruption (97/783/JAI, OJ L 320 of 21.11.1997).

${ }^{41}$ COM (97) 192 final of 21.5.1997.

${ }^{42}$ Action plan of the Council and the Commission on how best to implement the provisions of the Treaty of Amsterdam on an area of freedom, security and justice, adopted by the Council on 3 December 1998 (OJ C 19 of 23.1.1999).

${ }^{43}$ OJ C 408 of 29.12.1998.
} 
Following the line traced by the former documents, the European Union Strategy for the beginning of the new millennium on the prevention and control of organised crime $(2000)^{44}$ stressed the need for more general EU policy towards a number of crimes, including corruption, for an approximation of the legislation of Member States, and for the ratification of the existing instruments concerning these matters.

Despite the number of legal documents on corruption at the EU level, it is evident that when the $21^{\text {st }}$ century had already started, only a few Member States had done steps forward in this field. ${ }^{45}$ Aware of this situation, the Commission adopted the Communication on a comprehensive EU policy against corruption in $2003^{46}$ with the aim of giving "fresh impetus to the fight against corruption", It offers an overview of what had been achieved at EU level, and lists a number of issues to be improved. This list includes the ratification of the EU and international anti-corruption instruments, the monitoring of the implementation of these instruments, the improvement of judicial and police cooperation within the EU through Eurojust and Europol, the fight against private corruption, the improvement of the existing anti-corruption laws, the reinforcement of the integrity of the European Public Administration, and the adoption of new initiatives focused on preventive measures. As it can be observed, it is a long list that actually shows that, already in the $21^{\text {st }}$ century, there was still much work to do in the fight against corruption at the EU level, and that situation was so despite of the fact that corruption had already been in the EU agenda for many years. Indeed, the EU Convention against corruption had been adopted six years before, although it had not entered into force yet; a very questionable attitude of the Member States towards the EU anti-corruption policy.

In 2005, the Hague Programme: Strengthening Freedom, Security and Justice in the European Union ${ }^{47}$ included the fight against cross-border organised crime among its main objectives. In this context, once again, corruption, as a behaviour typically linked to organised crime, should be also combated, as a comprehensive strategy in the fight against organised crime. This idea is also underlined in the Communication from the Commission to the Council and the European Parliament "Developing a strategic concept on tackling organised crime", ${ }^{48}$ which considers corruption as a key tool by which organised crime infiltrates in licit markets.

Following the instructions of the Hague Programme, the Council adopted the Decision 2008/852/JHA of 24 October 2008 on a contact-point network against corruption ${ }^{49}$, the aim of which is to set up such a network in order to improve the cooperation between authorities and agencies to prevent and combat corruption in Europe. This document is really crucial because one of the main shortcomings in combating corruption is, precisely, the prosecution of criminals. This is why cooperation among countries is one of the key points of an effective criminal policy against corruption. In this era, in which

\footnotetext{
${ }^{44}$ OJ C 124 of 3.5.2000.

45 Take into account that some of the EU legal documents on corruption adopted in the middle of the nineties had no entered into force yet, due to the reluctance of some Member States to ratify them.

${ }^{46}$ Communication from the Commission to the Council, the European Parliament and the European Economic and Social Committee on a Comprehensive EU Policy Against Corruption, COM(2003) 317 final, 28.5.2003.

${ }^{47}$ OJ C 53 of 3.3.2005.

${ }^{48}$ COM (2005) 232 final of 2.6.2005.

${ }^{49}$ OJ L 301 of 12.11.2008.
} 
criminality, in general, and corruption, in particular, knows no borders, merely national initiatives are ineffective. Therefore, States must cooperate and help each other in struggling corruption. It cannot be ignored that when preventive measures do not work and the offences are committed, then criminals must be prosecuted, and cooperation is essential to achieve this goal.

The Stockholm Programme - An Open and Secure Europe Serving and Protecting Citizens ${ }^{50}$ mentions corruption among the offences that "continue to challenge the internal security of the Union" 51 and invites the Commission to develop indicators to measure efforts in the fight against corruption and to develop a comprehensive anticorruption policy in close cooperation with the Council of Europe Group of States against Corruption (GRECO). ${ }^{52}$ In order to comply with those anti-corruption provisions of the Stockholm Programme, a number of documents have been adopted. For instance, the Communication from the Commission to the European Parliament, the Council and the European Economic and Social Committee - Fighting Corruption in the EU, ${ }^{53}$ which developed the Stockholm Programme's objectives in detail; the Commission Decision Establishing an EU Anti-corruption reporting mechanism for periodic assessment ("EU Anti-corruption Report"), ${ }^{54}$ the Commission Decision setting up the Group of Experts on Corruption, ${ }^{55}$ and the Communication from the Commission to the European Parliament, the Council and the European Economic and Social Committee: Participation of the European Union in the Council of Europe Group of States against Corruption (GRECO). ${ }^{56}$

Finally, the EU Anti-corruption Report, elaborated by a group of experts under the supervision of the Commission was launched in February 2014. ${ }^{57}$ Some data contained in it are used in the following sections to assess the EU criminal policy against corruption.

\section{Anti-corruption legal documents binding to Member States}

3.1. From the fight against corruption linked to the protection of the Communities' financial interests to the fight against corruption beyond the protection of the Communities' financial interests

The anti-corruption legal documents binding to Member States were adopted within the third pillar, in particular, on the basis provided by Article K.3 of the Treaty of Maastricht, which offered the legal framework to draw up conventions in areas of common interests, such as combating fraud on a supranational scale. For this reason, at the beginning, the fight against corruption was totally linked to the protection of the financial interests of the European Communities, despite the fact that corruption has

\footnotetext{
${ }^{50}$ OJ C 115 of 4.5 .2010 .

${ }^{51}$ The Stockholm Programme, p. 17.

52 GRECO is an entity created by the Council of Europe which aims at improving the capacity of its members to fight corruption. See https://www.coe.int/en/web/greco (last access 22.12.2017).

${ }^{53}$ COM (2011) 308 final of 6.6.2011.

${ }^{54} \mathrm{C}$ (2011) 3673 final of 6.6.2011.

${ }^{55}$ OJ C 284 of 30.9.2011.

${ }^{56} \mathrm{COM}$ (2012) 604 final of 19.10.2012.

57 EUROPEAN COMMISION, Report from the Commission to the Council and the European Parliament. EU Anti-corruption Report, Brussels, 3.2.2014, COM (2014) 38 final (hereinafter, EU Anticorruption Report). Available at https://ec.europa.eu/home-affairs/what-we-do/policies/organized-crimeand-human-trafficking/corruption/anti-corruption-report en (last access 22.12.2017).
} 


\section{Polít. crim. Vol. 15, № 27 (Julio 2019), Art. 15, pp. 520-548 \\ [http://politcrim.com/wp-content/uploads/2019/06/Vol14N27A15.pdf]}

other adverse effects, as was indeed pointed out in the aforementioned Resolution on combating corruption in Europe in 1995.

The Convention on the protection of the European Communities' financial interests, ${ }^{58}$ adopted in 1995 (hereinafter, PFI Convention), requires Member States to penalise certain conducts that may put the financial interests at risk, such as any act or omission relating to the use or presentation of false, incorrect or incomplete statements or documents, which has as its effect the misappropriation or wrongful retention of funds from the general budget of the European Communities or budgets managed by, or on behalf of, the European Communities; non-disclosure of information in violation of a specific obligation, with the same effect, and the misapplication of such funds for purposes other than those for which they were originally granted (Article 1).

Nevertheless, the PFI Convention did not mention corruption as a conduct likely to put the Communities' financial interests at risk, which is not easy to understand since it is clear that corruption may affect the financial interests and this fact should have been stated by the PFI Convention. Therefore, a Protocol was added to the Convention one year later (hereinafter, PFI Protocol) ${ }^{59}$. It established the first legal obligations concerning corruption to be implemented by Member States. Thus, and as said, being aware that "the financial interests of the European Communities may be damaged or threatened by other criminal offences, particularly acts of corruption by or against national and Community officials, responsible for the collection, management or disbursement of Community funds under their control", 60 the Protocol demands Member States to criminalise passive and active corruption of any national official, including any official of another Member State, and Community officials in a way which damages or is likely to damage the European Communities' financial interests. Note that "Passive corruption" refers to the conduct of the public official who request or accepts the bribe, while "active corruption" refers to the conduct of the individual who offers or gives the bribe.

The importance of the PFI Protocol is unquestionable since it is the first compulsory document at the EU level in the field of corruption, the first of a long list. Nevertheless, as usual in pioneer documents, it had a number of lacks, which were not corrected by the subsequent document adopted, as it will be explained.

Only one year after the adoption of the PFI Protocol, and for the reasons explained below, a new instrument on corruption came to light: the Convention on the fight against corruption involving officials of the European Communities or officials of Member States of the European Union (hereinafter, EU Convention on corruption). ${ }^{61}$ As said in the introduction to this paper, this is the most relevant document on corruption at the EU level. Inspired by the PFI Protocol, the EU Convention on corruption also

\footnotetext{
${ }^{58}$ Convention drawn up on the basis of Article K.3 of the Treaty on European Union, on the protection of the European Communities' financial interests, of 26 July 1995 (OJ C 316 of 27.11.1995). Entry into force: 17.10.2002.

${ }^{59}$ Protocol drawn up on the basis of Article K.3 of the Treaty on European Union to the Convention on the protection of the European Communities' financial interests, of 27 September 1996 (OJ C 313 of 23.10.1996. Entry into force: 17.10 .2002$)$.

${ }^{60}$ Preamble of the PFI Protocol.

${ }^{61}$ Convention drawn up on the basis of Article K.3 (2) (c) of the Treaty on European Union on the fight against corruption involving officials of the European Communities or officials of Member States of the European Union, of 26 May 1997 (OJ C 195 of 25.6.1997). Entry into force: 28.9.2005.
} 
requires Member States to criminalise passive and active corruption involving the aforementioned officials, but it has a broader scope of application since it does not restrict the punishment of such conducts to attacks on the financial interests of the EU.

When it comes to the reasons for the adoption of the EU Convention on corruption, a preliminary reflection exercise could make us think that the Council understood that corruption has other negative effects apart from the attack on the Communities' financial interests, and therefore it elaborated this general Convention in line with the legal documents that were being drafted in other international fora. ${ }^{62}$ Nevertheless, the Preamble of the EU Convention on corruption indicates, as the only reason, "the purpose of improving judicial cooperation in criminal matters between Member States". Certainly, the element "damage or likelihood of damage the European Communities' financial interests" was an obstacle to the judicial cooperation since it required additional evidentiary elements ${ }^{63}$. But even so, it is quite odd that this was the only motive to modify the EU Convention, and that no other motives were mentioned, such as the fact that the corruption may have other devastating consequences apart from the damage to the financial interests.

On the other hand, neither the PFI Protocol nor the EU Convention on corruption dealt with some crucial issues to combat bribery, namely, money laundering, liability of legal entities involved in corruption cases ${ }^{64}$ and assets recovery. Therefore, a Second Protocol concerning these issues was added to the PFI Convention in $1997^{65}$ (hereinafter, Second Protocol). However, the adoption process of the Second Protocol is somehow illogical. Since the EU Convention on corruption had already been adopted, it would have been more reasonable to regulate these three issues in a Protocol to the EU Convention on corruption rather than to the PFI Convention because, as said, the latest is limited to conducts that damage or are likely to damage the Communities' financial interests.

Recently, the Directive (EU) 2017/1371 ${ }^{66}$ has ordered the replacement of the PFI Convention and its Protocols by the 6 July 2019. ${ }^{67}$ The Directive gives a new impetus to the fight against fraud to the Union's financial interests, by requiring Member States the criminalisation of a number of conducts that may affect such interests, namely fraud (Article 3), money laundering (Article 4.1), corruption (Article 4.2) and misappropriation (Article 4.3). It is true that these types of offences were already

62 GALLEGO-CASILDA GRAU, Yolanda, 'The European Union's initiatives in the fight against corruption', in ALVAZZI DEL FRATE, Anna; PASQUA, Giovanni (eds), Responding to the Challenges of Corruption, UNICRI / ISPAC / CNPDS, Rome / Milan, 2000, p. 189.

63 KAIAFA-GBANDI, Maria, 'Punishing Corruption in the Public and the Private Sector: The Legal Framework of the European Union in the International Scene and the Greek Legal Order', European Journal of Crime, Criminal Law and Criminal Justice, n. 18 (2010), pp. 139-183, p. 154.

${ }^{64}$ The EU Convention on corruption, however, does foresee the criminal liability of heads of businesses (Art 6) with the aim of ensuring that these persons or other persons exercising legal or effective power within a business are not automatically exempt from all criminal liability where active corruption has been committed by a person under their authority acting on behalf of the business. See, in detail, the Explanatory Report on the Convention on the fight against corruption involving officials of the European Communities or officials of Member States of the European Union (OJ C 391 of 15.12.1998), section 6.1.

${ }^{65}$ Second Protocol drawn up on the basis of Article K.3 of the treaty on European Union, to the Convention on the protection of the European Communities' financial interests, of 19 June 1997 (OJ C 221 of 19.7.1997). Entry into force: 19.5.2009.

${ }^{66}$ Directive (EU) 2017/1371 of the European Parliament and of the Council of 5 July 2017 on the fight against fraud to the Union's financial interests by means of criminal law (OJ L 198 of 28.7.2017).

${ }^{67}$ From that date on, references to the Convention shall be construed as references to this Directive. 


\section{Polít. crim. Vol. 15, № 27 (Julio 2019), Art. 15, pp. 520-548 \\ [http://politcrim.com/wp-content/uploads/2019/06/Vol14N27A15.pdf]}

included in the aforementioned EU documents on corruption, with the exception of misappropriation, which had been ignored by all anti-corruption documents, so that the reference to this conduct in the Directive must be welcome because it may have truly serious consequences for the financial interests of the European Union since it is directly related to the management of public funds. Besides, the new Directive is very relevant because it offers an updated definition of fraud, foresees the harmonization of penalties and establishes a new aggravating circumstance when the offence is committed within a criminal organisation. Moreover, the Directive contains provisions concerning sanctions for legal persons, which did not appear in the Second Protocol, and provisions regarding two institutions which must be considered essential in the fight against corruption and other economic crimes, that is, freezing and confiscation of instrumentalities and proceeds from the aforementioned criminal offences. ${ }^{68}$

The EU legal documents mentioned so far did not take into account corruption in the private sector. The reason may be found in the fact that the concept of corruption had been traditionally linked to the public sector only. Over time, the European Union, as well as other international organisations, ${ }^{69}$ understood that the methodology employed by corrupt people in the public sector is applicable to the private sector too ${ }^{70}$ and that the effects of this kind of corruption may also be very negative for economic growth, because it seriously distorts free competition and, in particular, undermines the smooth functioning of the internal market. Aware of this, the EU adopted in 1998 the Joint Action 98/742/JHA, on corruption in the private sector, ${ }^{71}$ which demanded Member States to criminalise active and passive corruption in this field. The Joint Action was replaced some years later by the Framework Decision 2003/568/JHA on combating corruption in the private sector, ${ }^{72}$ with the aim of ensuring that both active and passive corruption in this field are criminal offences in all Member States. The criminalisation of these conducts goes beyond the protection of the Union's financial interests. Corruption in the private sector is a matter that affects citizens in general since, in the end, its main consequence is the increase of the price of goods and services.

\subsection{Obligations imposed by the anti-corruption legal documents}

The EU Convention on corruption is completely inspired by the PFI Protocol. In fact, the contents are the same except for the reference to the Communities' financial interests. ${ }^{73}$ For this reason, this section will focus on the Convention and on the Second

\footnotetext{
${ }^{68}$ Vid., on this respect, the Directive 2014/42/EU of the European Parliament and of the Council of 3 April 2014 on the freezing and confiscation of instrumentalities and proceeds of crime in the European Union (OJ L 127 of 29.4.2014).

${ }^{69}$ See, for instance, the Council of Europe Criminal Law Convention on Corruption of year 1999 (Articles 7 and 8) and the UNCAC of year 2003 (Article 21).

${ }^{70}$ STESSENS, Guy, 'The international fight against corruption. General Report', Revue Internationale de Droit Pénal, n. 72, 3-4 (2001), pp. 891-937, p. 914.

${ }^{71}$ Joint Action 98/742/JHA adopted by the Council on the basis of Article K.3 of the Treaty on European Union, on corruption in the private sector, of 22.12.1998 (OJ L 358 of 31.12.98).

72 Council Framework Decision 2003/568/JHA on combating corruption in the private sector, of 22.7.2003 (OJ L 192 of 31.7.2003).

${ }^{73}$ White adds another difference. In her opinion, a conjoint reading of the PFI Protocol and the PFI Convention suggests that cooperation is restricted to criminal matters. The EU Convention on corruption, by contrast, could be interpreted to mean that administrations have a duty to cooperate in cases of suspected corruption, even if the behaviour in question was not object of criminal sanctions. WHITE, Protection of the Financial Interests..., cit. note n. 34, p. 158. This is a relevant distinction since, traditionally, it has been more difficult to cooperate in criminal matters than in other matters. In addition,
} 
Protocol only, not on the PFI Protocol. Likewise, it will focus on the obligations concerning corruption in the private sector.

\subsubsection{Definition of "official"}

According to Article 1(a) of the EU Convention on corruption, the term "official" includes any Community official or national official of another Member State. The Convention defines "Community official" as any employee within the meaning of the Staff Regulation of the European Communities or seconded person carrying out corresponding functions (Article 1.b). Nevertheless, the concept of "national official" remains undefined, and it shall be understood by reference to the definition of "official" and "public officer" in the national law of the Member State in which the person in question performs that function (Article 1.c) This provision must be criticised because it means that the same conduct may be an offence in one Member State and not in another, depending on the definition of each one, ${ }^{74}$ which can hinder the cooperation between countries. In order to avoid this problem, it is necessary a common definition of public official, like the one employed, for instance, by the UNCAC. ${ }^{75}$ The new Directive (EU) 2017/1371 still does not resolve this problem since it contains the same provision concerning the reference to the Member States' laws with respect to the definition of national official. The aforementioned definition of European official does not include members of the Commission, the Parliament, the Court of Justice and the Court of Auditors, but Article 4 of the EU Convention refers to them. This provision requires Member States to assimilate them to national government ministers, elected members of their parliamentary chambers, members of their highest Courts and members of their Courts of Auditors. So that they shall ensure that anti-corruption provisions in their respective criminal laws relating to national officials apply similarly in cases relating to EU officials. Certainly, what the Convention does here is just to comply with the wellknown principle of assimilation, firstly applied in this area in the Greek Maize case (Case 68/88, Commission v. Greece, 1989).

administrative authorities are usually in a better position to cooperate. POSADAS, Alejandro, 'Combating corruption under international law', Duke Journal of Comparative \& International Law, n. 10 (2010), pp. 345-414, p. 398.

${ }^{74}$ KAIAFA-GBANDI, 'Punishing Corruption...', cit. note n. 63, p. 155-156 MITSILEGAS, Valsamis, 'The aims and limits of the European Union Anti-corruption Law', in HORDER, Jeremy; ALLDRIDGE, Peter. (eds.), Modern Bribery Law. Comparative Perspectives. Cambridge University Press, p. 173; WOLF, Sebastian, 'Der Beitrag internationaler und supranationaler Organisationen zur Korruptionsbekämpfung in den Mitgliedstaaten', Speyerer Forschungsberichte, n. 253 (2007), p. 25. Think about the case of a bribery request by a Spanish congressman and by a German congressman. Congressmen are "public officials" (funcionarios públicos) in Spain, but they are not (Amtsträger) in Germany. The result is that the conduct is an offence of passive corruption under the Spanish national law, but it is not an offense of passive corruption under the German national law. However, these behaviours do not remain unpunished under German national law. It is another type of offence ("buying or selling votes").

${ }^{75}$ Article 2 of the UNCAC. Use of terms. For the purposes of this Convention: (a) "Public official" shall mean: (i) any person holding a legislative, executive, administrative or judicial office of a State Party, whether appointed or elected, whether permanent or temporary, whether paid or unpaid, irrespective of that person's seniority; (ii) any other person who performs a public function, including for a public agency or public enterprise, or provides a public service, as defined in the domestic law of the State Party and as applied in the pertinent area of law of that State Party; (iii) any other person defined as a "public official" in the domestic law of a State Party. However, for the purpose of some specific measures contained in chapter II of this Convention, "public official" may mean any person who performs a public function or provides a public service as defined in the domestic law of the State Party and as applied in the pertinent area of law of that State Party (...). 
Finally, last paragraph of Article 4 states that the Convention shall apply in full accordance with the relevant provisions concerning the withdrawal of immunity. This immunity is foreseen by the Protocol $\left(\mathrm{n}^{\circ} 7\right)$ on the privileges and immunities of the European Union $^{76}$, according to which, immunity of Community officials may only be waived by each Community institution, and only if that institution considers that the waiver of such immunity is not contrary to the EU interests (Article 17). Here, it must be remarked that waiving the immunity in order for the EU official to be sent to the Court shall not be understood as something contrary to the Union's interests. Just the opposite, it is the hindering prosecution of corruption offences allegedly committed by and EU official that does go against the Union's interests.

\title{
3.2.2. The offences of passive and active corruption
}

The Convention includes a classical definition of "passive" and "active" corruption. The first one is defined as

\begin{abstract}
"the deliberate action of an official, who, directly or through an intermediary, requests or receives advantages of any kind whatsoever, for himself or for a third party, or accepts a promise of such an advantage, to act or refrain from acting in accordance with his duty or in the exercise of his functions in breach of this official duties" (Article 2.1).
\end{abstract}

Active corruption is defined as

"the deliberate action of whosoever promises or gives, directly or through an intermediary, an advantage of any kind whatsoever to an official for himself or for a third party for him to act or refrain from acting in accordance with his duty or in the exercise of this functions in breach of his officials duties" (Article 3.1).

With respect to these definitions, it is necessary to make some clarifications concerning the constituent elements of the offences of corruption. ${ }^{77}$ First, the conduct may be carried out "directly or through an intermediary"; phrase that is very relevant because the presence of a third party is not unusual in this kind of behaviours since it can be difficult to access directly the person who can benefit whosoever with his act or omission. The responsibility of the third party, that is, the intermediary, will depend upon his knowledge.

Second, the Convention puts an end to the traditional discussion in many Member States related to the term "advantage", which must now include not only material objects (e.g. money, precious objects) but also intangible advantages (e.g. privileges, promotions).

Third, it is understood that there is also an offence of corruption although the advantage is not for the official but for a third party, such as a relative, a close friend or even a legal entity (e.g. a political party). That is, it is not necessary that the bribery benefits the official in question, although it does seem to be necessary the existence of a

\footnotetext{
${ }^{76}$ OJ C 326 of 26.10 .12 .

77 For a detailed description of the constituent elements of the offences, see the aforementioned Explanatory Report on the EU Convention on corruption.
} 
relationship between the person who ultimately receives the benefit and the official who acts or refrains from acting motivated by the bribery.

Fourth, the request, acceptance, giving or promise of the bribery must, in principle, predate the official's act or omission. Therefore there is not the obligation on Member States to criminalise such conducts when the advantage is received after an act has been performed without the existence of a prior agreement. However, the convention only contains minimum rules, as Article 11 states, so that, Member States may opt for the criminalisation of further conducts, such as subsequent corruption. ${ }^{78}$

Finally, the Convention applies to performance of, or abstention from performing, any act within the powers of the holder of the office or function by virtue of any law or regulation (official duty) in so far as the acts are carried out in breach of the official's duties. In addition, the Convention also covers cases where an official, contrary to his official duty to act impartially, receives an advantage in return for acting in accordance which this function (e.g. by giving preferential treatment by accelerating or suspending the processing of a case).

When it comes to penalties, the Convention establishes that conducts of passive and active corruption, as well as participating and instigating the conducts in question, shall be punishable by effective, proportionate and dissuasive criminal penalties, including, at least in serious cases, penalties involving deprivation of liberty which can give rise to extradition (Article 5.1). This attempt at harmonisation is, however, misleading because, in the end, Member States are the ones that have to decide what criteria or elements will determine the seriousness of an offence in the light of their respective legal traditions, which can give as a result an uneven ranking of penalties. ${ }^{79}$ Directive (EU) 2017/1371 insists on the harmonization of sanctions, and it is more precise than former documents on the matter. Nevertheless, the Directive only generates obligations with respect to the offences mentioned above (fraud, corruption, money laundering and misappropriation) when they affect the financial interests of the European Union, which is very restrictive. In that attempt at harmonizing sanctions, the new Directive orders Member States to foresee a maximum penalty of at least four years of imprisonment when the offence involves considerable damage or advantage (Article 7.3). Actually, this is only a minimum rule, and national legal systems usually foresee higher penalties.

\footnotetext{
${ }^{78}$ This is the case of Spain (Article 421 of the Criminal Code).

${ }^{79}$ CARRERA HERNÁNDEZ, Francisco J., 'La persecución penal de la corrupción en la Unión Europea', in Cooperación jurídica internacional, Madrid, 2001, p. 233. For instance, the imprisonment penalty for the most serious offence of passive corruption (in breach of official duties) is 6 months to 5 years in Germany, 6 to 10 years in Italy, and 3 to 6 years in Spain; in short, very different situations concerning penalties. There was, however, an attempt at harmonising penalties for corruption offences and other offences at the EU level: the Corpus Juris, a document prepared by a group of experts under the direction of Prof. Mireille DELMAS-MARTY. The Corpus Juris is not, however, compulsory for Member States. Article 5 refers to corruption offences committed by officials, and article 14 establishes penalties. So, for natural persons, it foresees a custodial sentence for a maximum of five years and/or a fine. Fines shall be determined according to the day fine system. A day fine corresponds to the daily income of the accused. This may be estimated freely by the court, but shall not exceed 3,000 Euros per day. The total fine shall not exceed three hundred and sixty five day fines. Moreover, additional penalties, such as a ban from Community and national public office for up to five years, may be imposed. See DELMAS-MARTY, Mireille; VERVAELE, John, The implementation of the Corpus Juris in the Member States. Penal provisions for the protection of European Finances, Intersentia, Brussels, 2000; DELMAS-MARTY, Mireille; VERVAELE, John, Un Derecho penal para Europa. Corpus Juris 2000: un modelo para la protección penal de los bienes jurídicos comunitarios, Dykinson, 2004.
} 
There is not an obligation to criminalise the attempt to commit passive or active corruption, since the offences include conducts that consist in making promises irrespective of whether such promises are actually kept or fulfilled. In any event, and as stated before, the EU Convention on corruption is an agreement on minimum standards, so that it allows Member States to adopt internal provisions that go beyond the obligations deriving from it.

\subsubsection{Prosecution of the offences of corruption}

Prosecuting offences of corruption is a very complex task due to a number of reasons. First of all, corruption is often referred to as a crime without a (direct) victim. ${ }^{80}$ The consequence of this is that it takes a long time until the offence comes to light, which may result in the expiration of the statute of limitation. Second, corruption has a transnational dimension nowadays, especially the corruption of EU officials, which can involve persons coming from several countries, e.g. the country where the offender or the official is one of its nationals, the country where the offence is committed, the country where the involving EU institution is placed, or the country of the victim's nationality. These circumstances hinder the prosecution of corruption offences. With the aim of addressing these issues which hinder the prosecution of corruption offences, the EU Convention on corruption foresees a number of provisions in Article 7 (jurisdiction).

The principle of territoriality is compulsory for all Member States. The three remaining principles are optional and they are aimed at providing for a sort of "extra-territoriality": principle of active nationality, principle of passive nationality, and a sui generis principle which allows a Member State to exercise its jurisdiction when the offender is a EU official working for a European institution or a body set up in accordance with the Treaties establishing the European Communities which has its headquarters in the Member State in question. The idea behind this provision is that the principle of territoriality may be insufficient to combat offences such as corruption, in which two elements are present: the internationality and the relationship with other criminal activities like organised crime and money laundering; activities which also may have themselves an international component. In short, provisions contained in Article 7 are aimed at reviewing the traditional jurisdiction principles to facilitate the prosecution of corruption offences.

On the other hand, one of the fundamental institutions in the fight against transnational crimes is extradition, regulated in Article 8 of the convention. The purpose of this provision is to avoid that the persons alleged to have committed acts of corruption go unpunished because extradition is refused on principle by the Member State of his nationality. Thus, Article 8 plainly sets out the principle aut dedere aut judicare. In any case, one cannot forget that Member States have now an instrument much more effective than the extradition, that is the European Arrest Warrant ${ }^{81}$, and they may employ it to prosecute crimes such as corruption

\footnotetext{
${ }^{80}$ Communication from the Commission to the Council, the European Parliament and the European Economic and Social Committee on a Comprehensive EU Policy Against Corruption, COM(2003) 317 final of 28.5.2003, p. 11.

${ }^{81}$ Council Framework Decision of 13 June 2002 on the European arrest warrant and the surrender procedures between Member States (2002/584/JHA) (OJ L 190 of 18.7.2002).
} 
Article 9 contains measures on cooperation, with the same goal of facilitating the prosecution of corruption offences, and in this sense, it requires Member States to work together in the investigation, the prosecution and in carrying out the punishment imposed by means, for example, of mutual legal assistance, extradition, transfer of proceedings and enforcement of sentences passed in another Member State.

Finally, the EU Convention on corruption demands Member States to respect the ne bis in idem rule, under which a person whose trial has been finally disposed of in a Member State may not be prosecuted in another Member States in respect of the same facts.

\subsubsection{Obligations under the Second Protocol}

Certainly, as said before, this Second Protocol will expire soon. In accordance with the aforementioned Directive (UE) 2017/1371, the validity of the Protocol will last until the 5 June 2019, when it will be replaced by the Directive. Until then, the Second Protocol requires Member States to adopt measures concerning three crucial issues in the fight against corruption that had been ignored by the EU Convention on corruption. First, they must penalise money laundering related to the proceeds of fraud, at least in serious cases, and of active and passive corruption (Article 2 of the Second Protocol). Second, they have to ensure that legal entities can be held liable for fraud, active corruption and money laundering (Article 3 of the Second Protocol). Sanctions for legal entities shall include criminal or non-criminal fines, ${ }^{82}$ and may comprise other sanctions such as the exclusion from entitlement to public benefits or aid, disqualification from the practice of commercial activities, placing under judicial supervision, and a judicial winding-up order (Article 4 of the Second Protocol). Third, Member States shall adopt measures to enable seizure and confiscation or removal of the instruments and proceeds of fraud, active and passive corruption (Article 5 of the Second Protocol).

The 2017 Directive encompasses similar obligations, according to which, Member States shall establish money laundering involving property derived from fraud, corruption and misappropriation as a criminal offence. The last one is new since misappropriation was not mentioned in former documents. Likewise, it insists on sanctioning legal persons and foresees new sanctions for them, such as the disqualification from the practice of commercial activities and the closure of establishments which have been used for committing the criminal offence. It also containes some provisions concerning the seizure and confiscation, taking into account the new EU legislation on this respect, basically, the aforesaid Directive 2014/42/EU on the freezing and confiscation of instrumentalities and proceeds of crime in the European Union.

\subsubsection{Obligations concerning corruption in the private sector}

The European Union was the first supranational organisation showing concern about corruption in the private sector. Certainly, neither the Interamerican Convention on

\footnotetext{
${ }^{82}$ At this point, the Second Protocol shows respect for the national systems in which legal entities cannot be responsible from the point of view of the criminal law. But in any case, the Explanatory Report to the Second Protocol insists on the need that sanctions for legal entities must have "certain punitive character in the sense of going beyond mere reparation of damages or restitution of wrongful enrichment". Explanatory Report on the Second Protocol to the Convention on the protection of the European Communities' financial interests, OJ C 91 of 31.3.1999, p. 12.
} 


\section{Polít. crim. Vol. 15, № 27 (Julio 2019), Art. 15, pp. 520-548 \\ [http://politcrim.com/wp-content/uploads/2019/06/Vol14N27A15.pdf]}

Corruption of 1996 nor the documents coming from the OECD in the nineties made any mention to the behaviours related to corruption in the private sector. Some years later, the Council of Europe Criminal Law Convention and the UNCAC did include a reference to this kind of conducts, both with respect to criminalisation and prevention.

At the EU level, it was the Joint Action 98/742/JHA, on corruption in the private sector, the first document that demanded Member States to criminalise passive and active corruption in the private sector, at least when these conducts involve, or could involve, the distortion of competition within the common market, and when they result, or might result, in economic damage to others by the improper award or improper execution of a contract. ${ }^{83}$

The Joint Action was replaced by the aforementioned Framework Decision 2003/568/JHA, according to which, active corruption is defined as

"promising, offering or giving, directly or through an intermediary, to a person who in any capacity directs or works for a private-sector entity an undue advantage of any kind, for that person or for a third party, in order that that person should perform or refrain from performing any act, in breach of that person's duties" (Article 2.1.a).

And passive corruption is defined as

"directly or through an intermediary, requesting or receiving an undue advantage of any kind, or accepting the promise of such an advantage, for oneself or for a third party, while in any capacity directing or working for a private-sector entity, in order to perform or refrain from performing any act, in breach of one's duties" (Article 2.1.b).

The Framework Decision contains very similar definitions of passive and active corruption with respect to the Joint Action but the scope of application is different since the Framework Decision allows for limiting the incrimination only to "conduct which involves, or could involve, a distortion of competition in relation to the purchase of goods or commercial services".

When it comes to sanctions, Article 4 establishes that these behaviours shall be punishable by effective, proportionate and dissuasive penalties. In addition, in an attempt at harmonising penalties at the EU level, the same Article indicates that these conducts shall be punishable by a penalty of a maximum of at least one to three years of imprisonment. The Framework Decision also worried about the liability of legal persons and regulates the issue in the same way than the Joint Action, by demanding Member States to take the necessary measures to ensure that legal persons can be held liable for the offences of active and passive corruption. Sanctions for legal entities shall include criminal or non-criminal fines, and may include others such as exclusion from entitlement to public benefits or aid, temporary or permanent disqualification from the practice of commercial activities, placing under judicial supervision, and a judicial winding-up order (Article 6).

Economic effects of corruption in the private sector are clear. It distorts free competition, one of the basic principles of the EU economy. Just for this reason, criminalisation of

\footnotetext{
${ }^{83}$ Articles 2(2) and 3(2) of the Joint Action 98/742/JHA
} 
these conducts could be justified. However, from the point of view of the criminal policy, it seems that there was not an appropriate debate over the criminalisation of these behaviours. In other words, it should have been discussed whether the best way to prevent corruption in the private sector is the criminal law or other branches of the legal systems, such as competition law. This debate was absent at the EU level and also in many Member States, most of which included new provisions on this matter in their respective criminal laws to simply comply with the EU mandates but without giving an opportunity to debate on the topic. This situation has had as a consequence the existence of some problems concerning the definition of the offence of corruption in the private sector, and a scarce enforcement of these new provisions, as explained below.

\section{Implementation and enforcement of the EU legal instruments against corruption}

As said above, EU Member States were initially reluctant to ratify the legal instruments against corruption adopted within the European Union, as proved by the fact that PFI Protocol lasted six years to entry into force, the EU Convention on corruption, eight years, and the Second Protocol, twelve years. Currently, all these documents are already in force, so that it must be certainly said that EU Member States have in place a clear list of legal instruments to combat corruption. In addition, there are other legal instruments on corruption adopted by other international organisations which are also compulsory to EU Member States, namely, the Council of Europe Conventions on Corruption and the United Nations Convention against Corruption. Likewise, the OCED Convention on Combating Bribery of Foreign Public Officials in International Business Transactions is mandatory for 24 Member States. So it is unquestionable that there is a very comprehensive legal framework to fight corruption at the EU level.

The implementation of the penal obligations contained in the EU legal instruments on corruption is, in general, satisfactory. Summarising, these instruments call the Member States to make the followings conducts a criminal offense: Active and passive corruption of national officials, active and passive corruption of EU officials, active and passive corruption of officials of other EU Member States, and active and passive corruption in the private sector.

Certainly, corruption of national officials has always been a criminal offense under the criminal law of all EU Member States. The criminalisation of corruption of EU officials and officials of other EU Member States is, by contrast, much more recent. Some EU Member States like Belgium ${ }^{84}$ and Germany ${ }^{85}$ incorporated such conducts to their criminal laws at the end of the nineties, while most of them did it already in the 2000s. ${ }^{86}$ Currently, the 28 Member States have incorporated provisions on this matter to their penal legislations. ${ }^{87}$ Note that most of them penalise corruption of foreign officials and officials of public international organisations in general, while others, like Germany, penalise separately, on the one hand, corruption of foreign officials and officials of public international

\footnotetext{
${ }^{84}$ Loi relative à la repression de la corruption, of 10.2.1999 (Moniteur belge of 23.3.1999)

85 Gesetz zu dem Protokoll vom 27. September 1996 zum Übereinkommen über den Schutz der finanziellen Interessen der Europäischen Gemeinschaften, EU-Bestechungsgesetz, EUBestG, of 10.9.1998 (Bundesgesetzblatt 1998 II p. 2340).

${ }^{86}$ Spain was one of the last Member States that implemented the EU penal obligations on corruption. The law that modify the Spanish criminal code to this respect came to light in year 2010 (Ley Orgánica 5/2010, por la que se modifica la Ley Orgánica 10/1995, de 23 de noviembre, del Código Penal, of 22.6.2010, Boletín Oficial del Estado 152, of 23.6.2010).

${ }^{87}$ See EUROPEAN COMMISION, EU Anti-corruption Report, cit. note n. 57. The Annex contains individual reports on each EU Member State.
} 


\section{Polít. crim. Vol. 15, № 27 (Julio 2019), Art. 15, pp. 520-548 \\ [http://politcrim.com/wp-content/uploads/2019/06/Vol14N27A15.pdf]}

organisations, and on the other hand, corruption of officials of EU Member States and EU officials. ${ }^{88}$ This distinction does not affect, however, penalties, which are the same for both cases. So, it can be stated that all Member States have implemented, although in different ways, the referred obligations. ${ }^{89}$

When it comes to the obligations concerning the incrimination of corruption in the private sector, it must be underlined that the implementation of the Framework Decision 2003/568/JHA has been highly problematic for Member States. Indeed, when the European Commission published a report over the transposition of such Framework Decision in $2011,{ }^{90}$ only nine Member States had correctly transposed all elements of the offence contained in Article 2 of the Framework Decision (incidentally, eight years after the adoption of the Framework Decision). ${ }^{91}$ Currently, all of them have transposed the Framework Decision, although some of them have done it partially only, (e.g. Estonia, Hungary, Latvia). In particular, there are shortcomings in the transposition of the provisions on criminalisation of all elements of active and passive corruption, as well as liability of legal persons. ${ }^{92}$ Therefore, Member States must continue working in this field.

When it comes to the enforcement of anti-corruption measures results are not very satisfactory. Indeed, the EU Anti-corruption Report of 2014 expressively states that "anti-corruption rules are not always vigorously enforced" by EU Member States, ${ }^{93}$ mainly because relevant institutions in this matter do not always have sufficient capacity to enforce the rules. This statement is, however, very general because the report does not specify if it refers to the enforcement of repressive rules or preventive rules, or both of them. For instance, the report does not offer data on the number of offences of corruption. This fact makes it difficult to assess the enforcement of the criminal law provisions concerning this matter. Actually, and as it is well-known in criminology, data collection of corruption offences is very challenging. ${ }^{94}$ Aware of this,

\footnotetext{
${ }^{88}$ See, with respect to corruption at the EU level, the aforementioned Gesetz zu dem Protokoll vom 27. September 1996 zum Übereinkommen über den Schutz der finanziellen Interessen der Europäischen Gemeinschaften, EU-Bestechungsgesetz. See, with respect to international corruption, Gesetz zu dem Übereinkommen vom 17. Dezember 1997 über die Bekämpfung der Bestechung ausländischer Amtsträger im internationalen Geschäftsverkehr, of 10.9.1998 (Bundesgesetzblatt 1998 II p. 2327). See, in detail, ZIESCHANG, Frank, 'Das EU-Besteschungsgesetz und das Gesetz zur Bekämpfung internationaler Bestechung', in Neue Juristische Wochenschrift, n. 2 (1999), pp. 105-107.

${ }^{89}$ In this way, Member States comply not only with the obligations required by the EU legal instruments, but also with the obligations required by the Council of Europe Criminal Law Convention on Corruption and the UNCAC, which demand the criminalisation of corruption of officials of any State and any public international organisation.

90 EUROPEAN COMMISSION, Report from the Commission to the European Parliament and the Council based on Article 9 of Council Framework Decision 2003/568/JHA of 22 July 2003 on combating corruption in the private sector, Brussels, 6.6.2011 COM (2011) 309 final (hereinafter, Report on combating corruption in the private sector).

${ }^{91}$ EUROPEAN COMMISION, Report on combating corruption in the private sector, cit. note n. 90, p. 7.

${ }^{92}$ EUROPEAN COMMISSION, EU Anti-corruption Report, cit. note n. 57, p. 13.

${ }^{93}$ EUROPEAN COMMISSION, EU Anti-corruption Report, cit. note n. 57, p.2.

${ }^{94}$ However, there are some relevant studies which develop indicators to measure these kind of crimes. See, for instance, AROMAA, Kauko; LEPPÄ, Seppo; NEVALA, Sami; OLLUS, Natalia (eds.), Crime and Criminal Justice in Europe and North America 115-1997: Report on the Sixth United Nations Survey on Crime Trends and Criminal Justice Systems, HEUNI, Helsinki, 2003 MALBY, Steven, 'Data collection on [new] forms and manifestations of crime', in JOUTSEN (Ed.), Matti, New Types of Crime. Proceedings of the International Seminar held in connection with HEUNI's thirtieth anniversary, Helsinki 20 October 2011, HEUNI publication no 74, Helsinki, 2012, pp. 120-133; VAN DIJK, Jan, 'The
} 
the European Commission included an action on the development of corruption indicators, followed by a pilot data collection, in the Action Plan on Crime Statistics 2011-2015. ${ }^{95}$ Data is already available. ${ }^{96}$ Nevertheless, the preparatory work revealed many differences between Member States concerning mainly the definition of the offences, the indicators for which the data is available, and the methodology employed to collect the information. For these reasons, the Expert Group on policy needs for data on crime warns that the information shall be interpreted with caution, particularly, when making comparisons between Member States. The document does not even show EU wide total data.

Besides, Transparency International published a report entitled "The European Union integrity system" in 2014, ${ }^{97}$ which focusses on the EU institutions only, not on the Member States. In spite of the comprehensive information it contains, it does not offer data on corruption offences either, but it states that corruption may still be a problem within the EU institutions. Indeed, the report says that although there is a good foundation in the EU system to support integrity and ethics, "this foundation is often undermined by poor practice, lack of political leadership, failure to allocate sufficient staff and funding, and unclarity about to whom the rules apply". ${ }^{98}$ Therefore, although the report highlights the improvements of the overall framework, it concludes that corruption risks still persist at the EU level, and identify as the most urgent risks the opacity in EU law-making and EU lobbing, the poorly managed conflicts of interests, the weak protection for EU whistleblowers and weak sanctions for corrupt companies.

Certainly, the first three risks mentioned above could be managed through preventive measures. At this point, we must remark that unfortunately the criminal policy against corruption at the EU level has been traditionally focused on criminalisation and punishment, ignoring prevention measures. As said, the PFI Protocols and the Convention of 1997 do not make any mention to the prevention, in contrast to other international documents on corruption, particularly, the UNCAC, which devotes a whole chapter to the prevention of corruption. The attitude of the EU, on the contrary, must be therefore criticised. In any case, the EU anti-corruption strategy has started to turn. An example of this is the recent Resolution on whistleblowers protection. ${ }^{100}$ This is not a binding document, but even so, it represents a progress in the fight against corruption. It is now time for the Commission to present a legislative proposal on this matter to tackle protection of whistleblowers in the European institutions as well as in

International Crime Victims Survey and Complementary Measures of Corruption and Organised Crime', Crime Prevention Studies, n. 22 (2007), pp. 125-144.

${ }^{95}$ Communication from the Commission to the European Parliament and the Council. Measuring Crime in the EU: Statistics Action Plan 2011-2015, COM (2011) 713 final.

${ }^{96}$ See

http://ec.europa.eu/transparency/regexpert/index.cfm?do=groupDetail.groupDetailDoc\&id=21215\&no=2 (last access 27.12.2017).

${ }^{97}$ HANCISSE, Louis, McMENAMIN, Amanda, PERERA, Mark; PATZ, Roony, The European Union Integrity System, Transparency International, 2014.

${ }^{98}$ HANCISSE / McMENAMIN / PERERA / PATZ, cit. note n. 97, p. 8.

${ }^{99}$ HANCISSE / McMENAMIN / PERERA / PATZ, cit. note n. 97, p. 8.

${ }^{100}$ European Parliament resolution of 24 October 2017 on legitimate measures to protect whistle-blowers acting in the public interest when disclosing the confidential information of companies and public bodies (2016/2224(INI)). 
Member States since it is crucial in the fight against corruption ${ }^{101}$ but, in spite of this, only a few Member States have comprehensive legislations on this matter.

Definitively, something is working wrongly in the EU criminal policy against corruption, both in the Member States and the EU institutions, and citizens are very aware of that. Indeed, according to the 2014 Anti-corruption Report, only under a quarter of respondents $(23 \%)^{102}$ agrees that their Government's efforts are effective in tackling corruption, which is worrying. It is true that this data does not say that governments do not do anything to combat corruption, but their initiatives are not assessed in a positive way by citizens, who still think that corruption is a widespread problem. Three quarters of respondents $(76 \%)$ think that corruption is widespread in their own country, and in some countries, this figure amounts to more than $90 \% .{ }^{103}$ Nevertheless, this data must be interpreted with caution because citizens' perceptions seem to be disproportionately higher than reality. In this sense, $26 \%$ consider that they are personally affected by corruption in their daily lives, and only $8 \%$ of the respondents say they have experienced or witnessed a case of corruption in the past 12 months.

As observed, information can be misleading because although a few people said to be personally affected by corruption, many of them believe that it is widespread. Probably, this confusing data is related to the existence of big scandals of corruption that appear in the media from time to time involving high level officials, ministers, members of the parliament and managers of multinational companies; scandals in which the numbers concerning the amount of money paid as briberies and money obtained as benefits are so huge that they shake the feelings of the citizens. In any case, citizens must be well informed to be able to build an opinion with respect to the functioning of the public institutions as well as the private companies. This is why it is essential to enhance the transparency, ensure the access to information, undertake public information activities, and promote and protect the freedom to seek, receive, publish and disseminate information regarding corruption. ${ }^{104}$

On the basis of the data exposed in the different reports mentioned in this section, the conclusion about the EU criminal policy against corruption is clear: notwithstanding the fact that there is a comprehensive legal framework on corruption, the results of the policies developed by Member States and EU institutions are not satisfactory at all, particularly, with respect to the enforcement of the measures adopted by Member States. Thus, fighting corruption continue to be a challenge at the EU level, and this is why EU Member States and the EU itself should focus on the improvement of such policies, as has been already pointed out by the GRECO, the OECD Working Group on Bribery and the Implementation Review Mechanism of the UNCAC in their evaluations on the implementation and enforcement of anti-corruption measures by EU Member States. ${ }^{105}$

101 COUNCIL OF EUROPE, Protection of Whistleblowers. Recommendation CM/Rec(2014)7 and explanatory memorandum, 2014, p. 11.

${ }^{102}$ It refers to the Eurobarometer surveys of 2013 on perceptions of corruption and experience of corruption

${ }^{103}$ E.g. Greece (99 \%), Italy (97\%), Lithuania, Spain and the Czech Republic (95\% in each)

${ }^{104}$ As stated in Article 13 of the UNCAC.

Evaluations are available
http://www.coe.int/en/web/greco/evaluations. $\quad \begin{gathered}\text { the } \\ \text { OECD: }\end{gathered}$


Particularly, the EU anti-corruption policy should put more emphasis on preventive measures, a field which was traditionally forgotten by the EU legal instruments on corruption adopted during the nineties. Those mainly worried about criminalisation, as the aforementioned instruments adopted by the Council of Europe and the OECD, ignoring a reality: "It is better to prevent crimes than to punish them" - to borrow the well-known words of Cesare Beccaria in his work Of Crimes and Punishments (1764). The UNCAC, by contrast, includes a whole chapter on preventive measures, expressing the change of the paradigm in this field. This is the path that the EU Member States and the EU itself should follow to eradicate corruption, or at least, to reduce it.

Alongside with the implementation and enforcement of preventive measures, it is crucial to strengthen police and judicial cooperation between Member States. As known, corruption is no longer a local matter, but a transnational phenomenon, which makes international cooperation indispensable to fight against it. Indeed, merely national initiatives do not seem to be very effective in combating this phenomenon. EU Member States have in place a very wide legal framework for police and judicial cooperation. Likewise, there are several agencies working on enhancing cooperation in criminal matters (Eurojust, Europol, the European Judicial Network). It is time to make a proper use of all them.

\section{Conclusions}

Corruption, understood as the abuse of entrusted power for private gain, has always been deemed as a threat to the financial interests of the European Union, and as such, a threat to the existence of the European Union itself. This is the reason why the EU started to concern about corruption already some decades ago. Indeed, the first attempt to adopt a legal instrument on corruption was in the seventies. Unfortunately, this attempt failed, and the real fight against corruption in the European Union did not begin until the middle nineties, wasting some years with respect to the anti-corruption policies of other countries such as the United States. During the 90's a number of legal instruments on corruption were adopted within the European Union. In the first ones, the fight against corruption appeared linked to the protection of the financial interests of the European Communities, so that the obligation of criminalising corruption behaviours of public officials was restricted to the fact that such behaviours affected the financial interests of the European Communities. This requirement was actually an obstacle in the fight against corruption. Therefore, the Convention on corruption of 1997 was adopted, demanding Member States the criminalisation of corruption behaviours of public officials irrespective of whether the financial interests were affected or not. The Convention of 1997 become so the main instrument against corruption at the EU level. Later, and taking into account that corruption is also an important problem in the private sector, not only in the public one, the EU adopted other documents on this matter, being the first supranational organisation in tackling this specific phenomenon.

The implementation of the mandates encompassed by the aforesaid documents is, broadly speaking, satisfactory. All Member States consider the corruption of national

bribery/countryreportsontheimplementationoftheoecdanti-briberyconvention.htm.

UNCAC: http://www.unodc.org/unodc/en/corruption/implementation-review-mechanism.html

(Last access 
officials, foreign officials and EU officials as criminal offences in their legal systems. Likewise, all of them criminalise corruption in the private sector too. Nevertheless, as the data shows, enforcement of such legislation seems to be far from straightforward, so that, fighting corruption is still an important challenge at the EU level. Therefore, it is essential that Member States continue working on the enforcement of anti-corruption strategies. These should include a number of measures both in the field of prevention and repression.

Firstly, it is extremely important the development of prevention policies, both in the public and private sector, which should include, among others, the promotion of transparency in areas such as public procurement and funding of political parties, the protection of whistleblowers and the awareness-raising about the causes and consequences of corruption.

Secondly, Member States must enforce the existing legislation on corruption offences, one again, both in the public and private sector. Particularly, they should pay attention to corruption of EU official, because anti-corruption policies have been traditionaly focused mainly on national official only, in spite of the fact that the EU legal documents expressly demand the criminalisation of such conducts. Likewise, Member States should also emphasise the enforcement of provisions concerning private sector because it is being scarce. In addition to this, Member States shall ensure that any corrupt behavior is punished with effective, proportionate and dissuasive penalties. Responsibility of legal entities cannot be ignored; therefore, they should be sanctioned in an effective, proportionate and dissuasive way too. To achieve that natural or legal persons are punished for having committed corruption offences, it is crucial to carry out an effective prosecution. And at this point, cooperation between Member States, and between them and the EU institution is essential since corruption is nowadays a transnational crime, therefore the fight against corruption demands coordinated policies with other countries.

Finally, and taking into account that corruption generates huge benefits for criminals, Member States and EU institutions shall also focus on the assets recovery since it constitutes a truly dissuasive measure for potential criminals as well as it is a mechanism that serves to achieve the material justice because the recovered assets could be invested in the territories where corruption caused devastating effects. 


\section{References}

ARNONE, Marco; BORLINI, Leonardo S., Corruption: Economic Analysis and International Law, Edward Elgar Publishing Limited, Northampton, 2014.

AROMAA, Kauko; LEPPÄ, Seppo; NEVALA, Sami; OLLUS, Natalia (eds.), Crime and Criminal Justice in Europe and North America 115-1997: Report on the Sixth United Nations Survey on Crime Trends and Criminal Justice Systems, HEUNI, Helsinki, 2003.

BERDUGO GÓMEZ DE LA TORRE, Ignacio; FABIÁN CAPARRÓS, Eduardo A., 'Corrupción y derecho penal: nuevos perfiles, nuevas respuestas'. Revista Brasileira de Ciências Criminais, n. 81 (2009), pp. 6-35.

CARRERA HERNÁNDEZ, Francisco J., 'La persecución penal de la corrupción en la Unión Europea', in Cooperación jurídica internacional, Madrid, 2001, pp. 207234.

CARTIER-BRESSON, Jean, 'The Causes and Consequences of Corruption: Economic Analyses and Lessons Learnt, No Longer Business As Usual', in No Longer Business as Usual. Fighting Bribery and Corruption, OECD Publications, Paris, 2000, pp. 11-28.

CHAIKIN, D.; SHARMAN, J.C., Corruption and Money Laundering. A Symbiotic Relationship, Palgrave Macmillan, New York, 2009.

CHÊNE, Marie, The impact of corruption on growth and inequality, Transparency International, 2014.

DELMAS-MARTY, Mireille; VERVAELE, John, The implementation of the Corpus Juris in the Member States. Penal provisions for the protection of European Finances, Intersentia, Brussels, 2000.

DELMAS-MARTY, Mireille; VERVAELE, John, Un Derecho penal para Europa. Corpus Juris 2000: un modelo para la protección penal de los bienes jurídicos comunitarios, Dykinson, 2004.

EUROPEAN COMMISSION, Report from the Commission to the Council and the European Parliament. EU Anti-corruption Report, Brussels, 3.2.2014, COM (2014) 38 final.

EUROPEAN COMMISSION, Report from the Commission to the European Parliament and the Council based on Article 9 of Council Framework Decision 2003/568/JHA of 22 July 2003 on combating corruption in the private sector, Brussels, 6.6.2011 COM (2011) 309 final.

EUROPEAN COMMISSION: Special Eurobarometer 397. Corruption. Report, February 2014.

FEROLA, Laura, 'Anti-Bribery Measures in the European Union: A Comparison with the Italian Legal Order', International Journal of Legal Information, n. 28-3 (2000), pp. 512-557.

GALLEGO-CASILDA GRAU, Yolanda, 'The European Union's initiatives in the fight against corruption', in ALVAZZI DEL FRATE, Anna; PASQUA, Giovanni (Ed.), Responding to the Challenges of Corruption, UNICRI / ISPAC / CNPDS, Rome / Milan, 2000, pp. 189-193. 
GARDINER, John 'Defining corruption', in HEIDENHEIMER, Arnold J.; JOHNSTON, Michael (Eds.), Political corruption. Concepts and Contexts, Transaction Publishers, 3rd edn., New Brunswick / London, 2005, pp. 25-40.

GOUNEV, P.; BEZLOV, T., Examining the links between organised crime and corruption, Center for the Study of Democracy, 2010.

GUPTA, Sanjeev; DAVOODI, Hamid; ALONSO-TERME, Rosa, Does Corruption Affect Income Inequality and Poverty?, International Monetary Fund Working Paper 98/76, 1998.

HANCISSE, Louis, McMENAMIN, Amanda, PERERA, Mark; PATZ, Roony, The European Union Integrity System, Transparency International, 2014.

HODGE, Andrew, SHANKAR, Sriram, RAO, D. S. Prasada; DUHS, Alan, Exploring the links between corruption and growth, School of Economics Discussion Paper, No. 392, School of Economics, University of Queensland, June 2009.

KAIAFA-GBANDI, Maria, 'Punishing Corruption in the Public and the Private Sector: The Legal Framework of the European Union in the International Scene and the Greek Legal Order', European Journal of Crime, Criminal Law and Criminal Justice, n. 18 (2010), pp. 139-183.

LAMBSDORFF, Johann G., 'Consequences and Causes of Corruption - What do We Know from a Cross-Section of Countries?' in ROSE-ACKERMAN, Susan (Ed.), International Handbook on the Economics of Corruption, Edward Elgar Publishing, Northampton, 2006, pp. 3-49.

MALBY, Steven, 'Data collection on [new] forms and manifestations of crime', in JOUTSEN (Ed.), Matti, New Types of Crime. Proceedings of the International Seminar held in connection with HEUNI's thirtieth anniversary, Helsinki 20 October 2011, HEUNI publication no 74, Helsinki, 2012, pp. 120-133.

MANACORDA, Stefano, La corruzione internazionale del pubblico agente. Linee dell'indagine penalistica, Casa Editrice Dott. Eugenio Jovene, Naples, 1999.

MAURO, Paolo, 'The Effects of Corruption on Growth, Investment, and Government Expenditure: A Cross-Country Analysis', in ELLIOT, Kimberly. A. (Ed.), Corruption and the Global Economy, Institute for International Economics, Washington, 1997, pp. 83-116.

MITSILEGAS, Valsamis, 'The aims and limits of the European Union Anti-corruption Law', in HORDER, Jeremy; ALLDRIDGE, Peter (eds.), Modern Bribery Law. Comparative Perspectives. Cambridge University Press, pp. 160-195.

NIETO MARTÍN, Adán, ‘¿Americanización o europeización del Derecho Penal económico?', Revista Penal, n. 19 (2007), pp. 120-136.

NIETO MARTÍN, Adán, 'La privatización de la lucha contra la corrupción', in ARROYO ZAPATERO, Luis; NIETO MARTÍN, Adán. (Dir.), El Derecho Penal Económico en la era compliance, Tirant lo Blanch, Valencia, 2013.

PELLEGRINI, Lorenzo; GERLAGH, Reyer, 'Corruption's Effects on Growth and its Transmission Channels', Kyklos, n. 57 (2004), pp. 429-456.

POSADAS, Alejandro, 'Combating corruption under international law', Duke Journal of Comparative \& International Law, 10 (2000), pp. 345-414.

ROSE-ACKERMAN, Susan; PALIFKA, Bonnie J., Corruption and Government: Causes, Consequences and Reform, Cambridge University Press, $2^{\text {nd }}$ edn., Cambridge, 2016.

SELIGSON, Mitchell A., 'The Impact of Corruption on Regime Legitimacy: A Comparative Study of Four Latin American Countries', The Journal of Politics, n. 64,2002 , pp. 408-433. 


\section{Decades of Efforts".}

SOTIS, Carlos, 'El huevo o la gallina: los intereses financieros de la Unión Europea y la armonización penal', DELMAS-MARTY, Mireille., PIETH, Mark; SIEBER, Ulrich. (Dir.), Los caminos de la armonización penal, Tirant lo Blanch, Valencia, 2009, pp. 331-349.

STESSENS, Guy, "The international fight against corruption. General Report", Revue Internationale de Droit Pénal, n. 72, 34 (2001), pp. 891-937.

SZAREK-MASON, Patrycja, The European Union's Fight Against Corruption. The Evolving Policy Towards Member States and Candidate Countries, Cambridge University Press, Cambridge, 2010.

TANZI, Vito, Corruption Around the World: Causes, Consequences, Scope, and Cures, International Monetary Fund Working Paper, 98/63, 1998.

TIVIG, Andrea; MAURER, Andreas, Die EU-Antikorruptionspolitik. Erfolgsbedingungen einer Korruptionsbekämpfung auf mehreren Ebenen, Diskussionspapier der FG 1, 2006/03, March 2006, SWP Berlin.

TRANSPARENCY INTERNATIONAL, Global Corruption Report, 2005.

TRANSPARENCY INTERNATIONAL, The Anti-Corruption Plain Language Guide, 2009.

VAN DIJK, Jan, 'The International Crime Victims Survey and Complementary Measures of Corruption and Organised Crime', Crime Prevention Studies, n. 22 (2007), pp. 125-144.

VERVAELE, John., 'Towards an independent European agency to fight fraud and corruption in the EU?', in ALBRECHT, Hans J.; KLIP, André (ed), Crime, Criminal Law and Criminal Justice in Europe, Martinus Nijhoff Publishers, Leiden / Boston, 2013, pp. 527-544.

WARNER, Carolyn M., 'Creating a Common Market for Fraud in the European Union', The Independent Review, n. 2 (2003), pp. 249-257.

WHITE, Simone, Protection of the Financial Interests of the European Communities: The Fight against Fraud and Corruption, Kluwer Law International, The Hague / London / Boston, 1998.

WOLF, Sebastian, 'Der Beitrag internationaler und supranationaler Organisationen zur Korruptionsbekämpfung in den Mitgliedstaaten', Speyerer Forschungsberichte, n. 253 (2007).

WOUTERS, Jan; RYNGAERT, Cedric; CLOOTS, Ann S., 'The international legal framework against corruption: Achievements and Challenges', Melbourne Journal of International Law, n.14 (2013), pp. 205-280.

ZIESCHANG, Frank, 'Das EU-Besteschungsgesetz und das Gesetz zur Bekämpfung internationaler Bestechung', en Neue Juristische Wochenschrift, n. 2 (1999), pp. 105-107. 